\title{
PANDANGAN BAKAL GURU AWAL KANAK-KANAK TERHADAP PENGHASILAN INFOGRAFIK KESIHATAN
}

\section{(PRE-SERVICE EARLY CHILDHOOD TEACHERS'VIEW ON CREATING HEALTH INFOGRAPHIC)}

\author{
Hidayah Mohd Fadzil \\ Department of Mathematics and Science Education, Faculty of Education, \\ University of Malaya, 50603 Kuala Lumpur, Malaysia \\ *E-mail: hidayahfadzil@um.edu.my
}

Publication date: 30 June 2020

To cite this article: Hidayah Mohd Fadzil. (2020). Pandangan bakal guru awal kanakkanak terhadap penghasilan infografik kesihatan. Asia Pacific Journal of Educators and Education, 35(1), 55-73. https://doi.org/10.21315/apjee2020.35.1.4

To link to this article: https://doi.org/10.21315/apjee2020.35.1.4

\begin{abstract}
Various studies have been conducted on the use of new technology in higher education. However, there are still limited references regarding the use of infographic and its effectiveness, particularly from educational context. Therefore, this study was conducted specifically to gain understanding of early childhood pre-service teachers' view on creating infographics as an innovation in continuous assessment at university level. This study is a qualitative study involving 27 second-year students majoring in Early Childhood Education as participants. It is conducted as a component of continuous assessment for Health and Safety course at a public university in Kuala Lumpur. Data is collected through document analysis which which involve analysis of the infographic created by the students and their reflection upon completing this task. The findings of the study were analysed using a constant comparative data analysis technique that involves coding, categorising and developing themes from information that emerges from the data collected, which could reflect the phenomenon under study. The findings generally expressed the students' positive attitude towards this assignment. The participants stated that this study enhances the conceptual knowledge about childhood illnesses and creates a meaningful learning experience for them as the task involves technology elements, in addition to the course content that is related to children's health. This assignment also helps the pre-service teachers in understanding effective infographic features. This study promotes innovation in teaching and learning in higher education institutions that also engage students in the use and application of the latest technology.
\end{abstract}


Keywords: Infographic, education technology, early childhood education, health education

\begin{abstract}
Abstrak: Pelbagai kajian telah dijalankan tentang penggunaan teknologi baharu dalam pendidikan tinggi. Namun, masih terdapat rujukan yang terhad berkaitan penggunaan infografik dan keberkesanannya, khususnya dari konteks pendidikan. Oleh itu, kajian ini dijalankan khusus untuk mendalami pandangan bakal guru awal kanak-kanak tentang penghasilan infografik sebagai inovasi dalam penilaian berterusan di universiti. Kajian ini merupakan kajian kualitatif yang melibatkan 27 orang pelajar tahun kedua jurusan Pendidikan Awal Kanak-kanak sebagai peserta kajian. Ia dijalankan sebagai komponen penilaian berterusan bagi kursus Kesihatan dan Keselamatan di sebuah universiti awam di Kuala Lumpur. Teknik pengumpulan data adalah melalui analisis dokumen iaitu analisis infografik yang dihasilkan dan refleksi pelajar setelah menyelesaikan tugasan ini. Dapatan kajian telah dianalisis menggunakan teknik analisis data komparatif yang melibatkan proses pengkodan, mengkategorikan dan membangunkan tema dari maklumat yang muncul dari data yang dikumpul, yang mana ia dapat menggambarkan fenomena yang sedang dikaji. Dapatan kajian secara umumnya menyatakan pandangan positif pelajar terhadap tugasan ini. Peserta kajian menyatakan bahawa kajian ini meningkatkan pengetahuan konsep tentang penyakit kanak-kanak dan mewujudkan satu pengalaman pembelajaran yang bermakna bagi mereka kerana tugasan ini melibatkan elemen teknologi, selain daripada kandungan kursus tentang kesihatan kanak-kanak. Tugasan ini juga membantu bakal guru dalam memahami ciri-ciri infografik yang berkesan. Kajian ini menggalakkan inovasi dalam pengajaran dan pembelajaran di institusi pendidikan tinggi yang turut melibatkan pelajar dalam penggunaan dan aplikasi teknologi terkini.
\end{abstract}

Kata kunci: Infografik, teknologi pendidikan, pendidikan awal kanak-kanak, pendidikan kesihatan

\title{
PENGENALAN
}

Dalam era globalisasi, penggunaan teknologi telah merevolusi cara manusia berkomunikasi. Perubahan yang pesat dalam teknologi ini turut menyumbang kepada perubahan pengajaran dan pembelajaran di institusi pengajian tinggi, iaitu dari pengajaran berpusatkan bilik darjah kepada pengajaran berpusatkan pelajar. Integrasi teknologi melengkapkan generasi baharu pelajar dengan kemahiran yang lebih luas untuk berjaya pada abad ke-21, di mana teknologi dianggap sebagai suatu alat penting dalam bidang pendidikan. Menurut Dias dan Atkinson (2001), integrasi teknologi dalam pendidikan tinggi merangkumi keseluruhan kontinum dari amalan pengajaran dan pembelajaran kendiri, perisian pembelajaran interaktif, penilaian dalam talian, akses kepada maklumat dalam talian, komunikasi dan penerbitan. Selain itu, Akinde (2016) menjelaskan integrasi teknologi dalam pendidikan ini turut didorong oleh tren dan perubahan semasa dalam teknologi pengajaran. Di institusi pendidikan tinggi, persekitaran pembelajaran berteknologi 
perlu disepadukan dalam pembangunan pendidikan kerana pengajaran berbentuk konvensional yang berpusatkan guru tidak lagi dapat memenuhi permintaan dan kehendak generasi digital. Infografik dianggap sebagai salah satu alat yang berkesan untuk komunikasi dan pemindahan maklumat (Ferreira, Baptista, \& Arroio, 2013; Lamb, Polman, Newman, \& Smith, 2014; Lazard \& Atkinson, 2015; Smiciklas, 2012). Oleh sebab ini, penggunaan infografik telah muncul sebagai pendekatan visual yang popular untuk menyampaikan kandungan pengajaran yang abstrak dan kompleks dalam menyokong pembelajaran (Lamb et al., 2014; Smiciklas, 2012; Vanichvasin, 2013). Kajian ini akan melihat kepada pandangan bakal guru awal kanak-kanak terhadap penghasilan infografik dalam tugasan kreatif yang memerlukan pelajar untuk mempraktikkan kemahiran teknologi digital.

\section{TINJAUAN LITERATUR}

Kombinasi teknologi, pedagogi dan pengetahuan kandungan semasa dalam pengajaran dan pembelajaran mempunyai kesan yang besar dalam memahami cabaran dan peluang dalam pengajaran dan pembelajaran dalam pendidikan tinggi (Lye, 2013). Dalam konteks Malaysia, "Dasar e-Pembelajaran Malaysia 2.0" telah diperkenalkan oleh Kementerian Pengajian Tinggi pada tahun 2011 khusus untuk menyokong Pelan Strategik Pengajian Tinggi yang memerlukan penyediaan rangka kerja e-Pembelajaran bertujuan untuk membangunkan modal insan kelas dunia yang berkualiti melalui penggunaan teknologi maklumat dan komunikasi (ICT). Oleh itu, pendidikan tinggi sepatutnya memenuhi permintaan yang semakin meningkat untuk pengetahuan dan kemahiran menerusi alat dan kaedah pedagogi yang inovatif.

Penggunaan media berteknologi sebagai alat pedagogi inovatif telah menjadi pendekatan popular dalam bidang pendidikan (Dabbagh \& Kitsantas, 2012; Ferreira et al., 2013; Potter \& Banaji, 2012). Banyak kajian yang telah melaporkan kejayaan pendidik dalam mengintegrasikan alat seperti blog, Wikipedia, dan rangkaian sosial ke dalam reka bentuk pengajaran dan penilaian (Fadzil, 2018; Ferreira et al., 2013; McLoughlin, 2011; Wolf, Beckem, \& Matias, 2011). Penggunaan visualisasi dalam pendidikan turut berkembang sejajar dengan perkembangan teknologi semasa ini. Menurut Moreno, Mayer, Spires dan Lester (2001), visualisasi adalah mod bukan lisan yang menjelaskan perkara berkaitan kandungan sesuatu pengetahuan. Ianya termasuk foto, ilustrasi, grafik, lukisan, peta, animasi, simulasi dan video. Infografik adalah sebahagian daripada visualisasi yang dapat memberi maklumat dengan cepat dan jelas (Lazard \& Atkinson, 2015; Smiciklas, 2012). 
Infografik didefinisikan sebagai reka bentuk grafik yang menggabungkan visualisasi data, illustrasi, teks dan gambar ke dalam format yang dapat memberikan suatu penjelasan menyeluruh (Krum, 2014). Toth (2013) dan Lamb dan Jhonson (2014) turut memberikan definisi yang hampir sama iaitu infografik sebagai bahan yang dihasilkan melalui gabungan visual dan teks yang memberikan maklumat tentang sesuatu subjek dalam bentuk yang mudah difahami. Maklumat dipersembahkan dalam bentuk aliran tertentu supaya penjelasan yang diberi adalah minimum, lebih efisien, dan pada masa yang sama dapat menunjukkan perhubungan antara setiap bahagian (Fadzil, 2018; Krum, 2014; Lester, 2011). Dalam erti kata lain, infografik menawarkan cara baharu untuk memberikan maklumat dengan urutan logik dalam membentangkan kandungan sesuatu topik dengan cara yang menarik (Abilock \& Williams, 2014; Lamb \& Jhonson 2014; Yildirim, 2017).

Oleh kerana infografik dapat memberikan banyak maklumat kompleks dengan mudah, ia dapat digunakan untuk tujuan lain seperti untuk mengingat maklumat, menunjukkan hubungan antara konsep, pemindahan sesuatu proses dan peristiwa, dan dalam meringkas sesuatu maklumat (Meeusah \& Tangkijviwat, 2013; Yildirim, 2017). Lamb et al. (2014) dan Smiciklas (2012) menerangkan infografik harus merangkumi butiran yang mencukupi dalam satu visual ringkas, dengan maklumat yang jelas dan tepat. Davidson (2014) dan Lamb dan Jhonson (2014) pula menegaskan infografik perlu mempunyai ciri self-explanatory. Oleh itu, dalam usaha untuk mencipta infografik yang menarik dan inovatif, pelajar memerlukan kemahiran berfikir secara kritikal, kemahiran menganalisis dan mensintesis maklumat (Hart, 2013; Yildirim, 2017).

Melihat kepada hakikat bahawa infografik telah diterima secara meluas dan digunakan sebagai alat untuk menyampaikan kandungan dengan cekap, ia telah digunakan secara meluas dalam menyampaikan kandungan pengajaran yang abstrak, kompleks dan padat (Dunlap \& Lowenthal, 2016; Siricharoen \& Siricharoen, 2015). Walaupun terdapat banyak penyelidikan yang dijalankan mengenai penggunaan teknologi dalam institusi pengajian tinggi, kajian berkaitan pengunaan infografik dalam pengajaran adalah sangat terhad, sama ada digunakan sebagai alat perkongsian maklumat, atau sebagai satu kaedah dalam pentaksiran pelajar (Dunlap \& Lowenthal, 2016; Fadzil, 2018; Siricharoen \& Siricharoen, 2015). Adalah penting bagi pendidik untuk memahami cara pelajar memproses maklumat yang terkandung di dalam infografik kerana infografik menyediakan cara untuk menjangkau pelajar dengan gaya pembelajaran yang berbeza, terutamanya pelajar yang cenderung dengan gaya pembelajaran berbentuk visual (Smiciklas, 2012; Lankow, Ritchie, \& Crooks, 2012). Oleh itu, tujuan kajian ini adalah untuk meneroka pandangan bakal guru awal kanak-kanak terhadap penghasilan infografik 
kesihatan dalam pengajaran dan pembelajaran kursus berkaitan kesihatan kanakkanak di sebuah universiti awam.

\section{METODOLOGI KAJIAN}

Kajian kualitatif ini melibatkan 27 orang pelajar tahun kedua (25 perempuan dan 2 lelaki) jurusan Pendidikan Awal Kanak-kanak yang berumur antara 21 hingga 24 tahun sebagai peserta kajian. Ia dijalankan sebagai komponen penilaian berterusan bagi kursus "Kesihatan dan Keselamatan" di sebuah universiti awam di Kuala Lumpur. Kursus ini memberi pendedahan kepada pelajar mengenai penjagaan kesihatan dan keselamatan dalam kalangan kanak-kanak di samping mendedahkan pelajar kepada berbagai masalah kesihatan yang akan timbul akibat kecuaian dalam menjaga kesihatan dan keselamatan mereka. Kursus ini dibahagikan kepada dua komponen utama iaitu komponen 'kesihatan' dan juga 'keselamatan'. Dalam komponen 'kesihatan', pelajar diminta untuk mereka bentuk infografik dengan menggunakan laman web yang tersedia secara dalam talian. Mereka diberi autonomi untuk mencipta infografik yang berkaitan dengan topik yang dipilih sendiri. Topik tersebut bagaimanapun mesti dikaitkan dengan penyakit dalam kalangan kanak-kanak. Tugasan dalam komponen 'kesihatan' ini telah digunakan sebagai sebahagian daripada komponen penilaian berterusan mereka dengan pemberat sebanyak $25 \%$.

Terdapat pelbagai laman web percuma untuk mereka bentuk infografik. Pelajar tersebut diperkenalkan kepada laman web seperti Canva, Piktochart, Venngage dan infogr.ams pada permulaan kursus, tetapi kemudian mereka perlu meneroka lebih lanjut dan memilih alat yang paling sesuai untuk digunakan dalam membuat infografik. Menurut Saat et al. (2016) dan Grieve, Padgett dan Moffitt (2016), pelajar masa kini tidak lagi mempunyai persepsi negatif mengenai penggunaan teknologi dalam pengajaran dan pembelajaran. Oleh itu, penyelidik beranggapan pelajar dapat meneroka sendiri dan mendapatkan maklumat tambahan dalam penyediaan infografik, dengan bimbingan khusus dari penyelidik. Semua maklumat berkaitan tugasan dikongsi ke portal e-pembelajaran bagi kursus (rujuk Rajah 1).

Proses penyediaan infografik Krauss (2012) telah digunakan untuk membimbing pelajar dalam kajian ini (rujuk Rajah 2). Penyelidik memainkan peranan sebagai pembimbing dan fasilitator sepanjang tempoh kajian ini. Pelajar kemudiannya dikehendaki membentangkan infografik mereka dalam sesi gallery walk pada akhir semester pengajian. Pada akhir tugasan ini, mereka juga dikehendaki untuk menyediakan satu refleksi mengenai pengalaman mereka dalam mencipta infografik dan memuat naik refleksi tersebut di portal e-pembelajaran. 

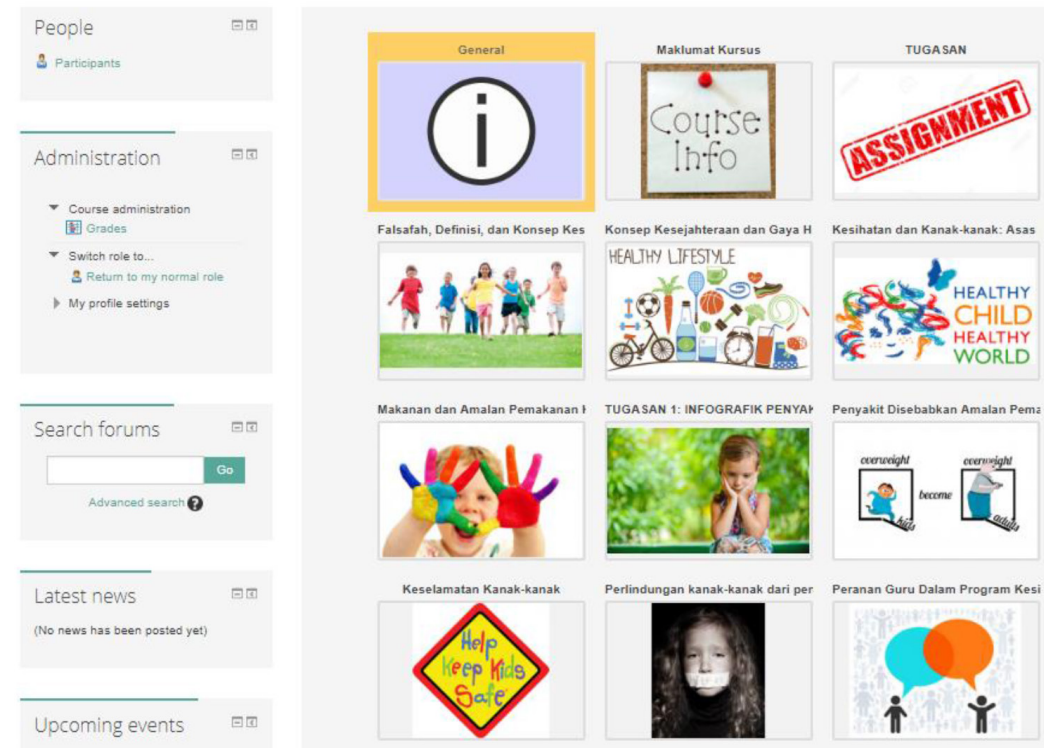

Rajah 1. Portal e-pembelajaran bagi kursus Kesihatan dan Keselamatan

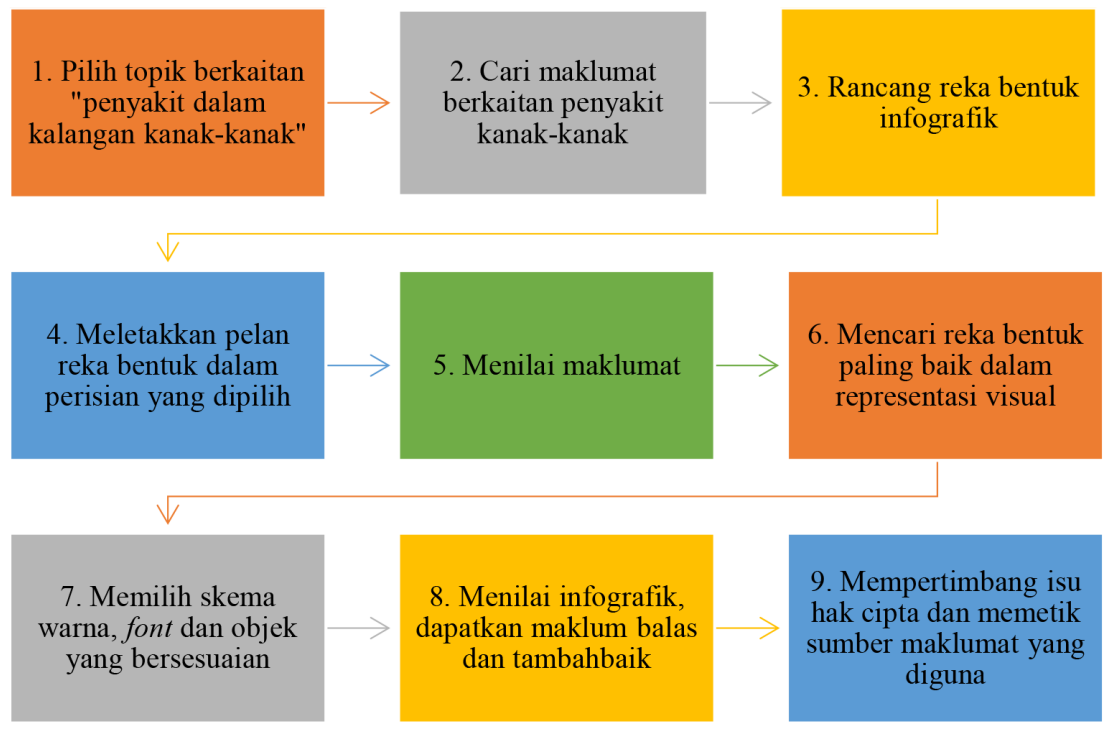

Rajah 2. Proses mereka bentuk infografik (adaptasi daripada Krauss, 2012) 
Infografik pelajar dianalisis dengan menggunakan rubrik yang menilai kesesuaian topik, kandungan infografik, objek, visualisasi data, organisasi maklumat dan kesahihan sumber yang digunakan dalam infografik. Manakala refleksi oleh peserta kajian dianalisis dengan menggunakan teknik analisis data komparatif (Glaser \& Strauss, 1967). Teknik analisis data komparatif ini melibatkan proses pengkodan, mengkategorikan dan membangunkan tema dari maklumat yang muncul dari data yang dikumpul, yang mana ia dapat menggambarkan fenomena yang sedang dikaji. Ini adalah selaras dengan pandangan Ritchie dan Spencer (1994) bahawa menyusun rangka kerja tematik ini melibatkan pemikiran logik dan intuitif untuk memastikan objektif penyelidikan dapat dicapai dengan tepat. Teknik analisis data ini digunakan untuk menjawab persoalan kajian. Selain itu, nota pemerhatian penyelidik juga digunakan untuk menyokong dapatan kajian ini.

Kesahan dan kebolehpercayaan adalah dua isu yang perlu diambil perhatian dalam penyelidikan kualitatif untuk menjamin kualiti dan ketepatan dapatan (Golafshani, 2003; Patton, 2002). Kesahan oleh pakar merupakan satu teknik yang digunakan untuk meningkatkan kredibiliti dan kebolehpercayaan penyelidikan kualitatif. Dalam kajian ini, dapatan yang diperoleh telah dinilai oleh dua orang pakar dalam bidang Teknologi Pendidikan dari sebuah universiti awam untuk memastikan kesesuaiannya. Pendekatan kedua yang dilaksanakan untuk meningkatkan kesahan kajian ini adalah melalui kaedah triangulasi. Triangulasi adalah satu kaedah untuk meningkatkan kesahan dalam penyelidikan untuk mengelakkan dapatan yang berat sebelah. Menurut Bryman (2006), triangulasi merujuk kepada penggunaan lebih daripada satu kaedah pengumpulan data untuk meningkatkan keyakinan terhadap dapatan. Triangulasi harus menyokong sesuatu dapatan, seperti yang didakwa oleh Greene, Caracelli dan Graham (1989). Melakukan pelbagai kaedah seperti pemerhatian, nota penyelidik, analisis infografik dan analisis refleksi pelajar akan membawa kita kepada penemuan yang lebih dipercayai dan tepat yang boleh mengurangkan ketidakpastian dalam tafsiran dapatan.

Sebelum memulakan kajian, pengkaji telah mendapatkan kebenaran bakal guru di mana semua peserta mengambil bahagian dalam kajian ini secara sukarela dan dijamin kerahsiaan dan privasi mereka. Mereka juga dikehendaki mengisi borang persetujuan dalam talian sebagai bukti penerimaan dan kesediaan mereka untuk menyertai kajian ini. 


\section{DAPATAN KAJIAN}

Dapatan menunjukkan bakal guru awal kanak-kanak dalam kajian ini dapat menghasilkan infografik yang bersifat informatif, berstruktur dan menarik secara visual (rujuk Rajah 3 dan 4). Antara infografik yang dihasilkan adalah berkaitan dengan penyakit kaki, tangan dan mulut, jangkitan cacing, batuk, demam campak dan penyakit mata. Tiga tema muncul dari analisis refleksi pelajar dan nota pemerhatian penyelidik iaitu: (1) infografik meningkatkan pengetahuan konsep pelajar tentang penyakit kanak-kanak, (2) infografik mencipta pengalaman pembelajaran yang bermakna, dan (3) tugasan membantu bakal guru dalam memahami ciri-ciri infografik yang berkesan. Walaupun kajian kualitatif ini melibatkan analisis data dari 27 orang peserta, hanya petikan yang bersesuaian dengan tema dapatan kajian sahaja yang akan digunakan dalam penulisan bahagian ini.

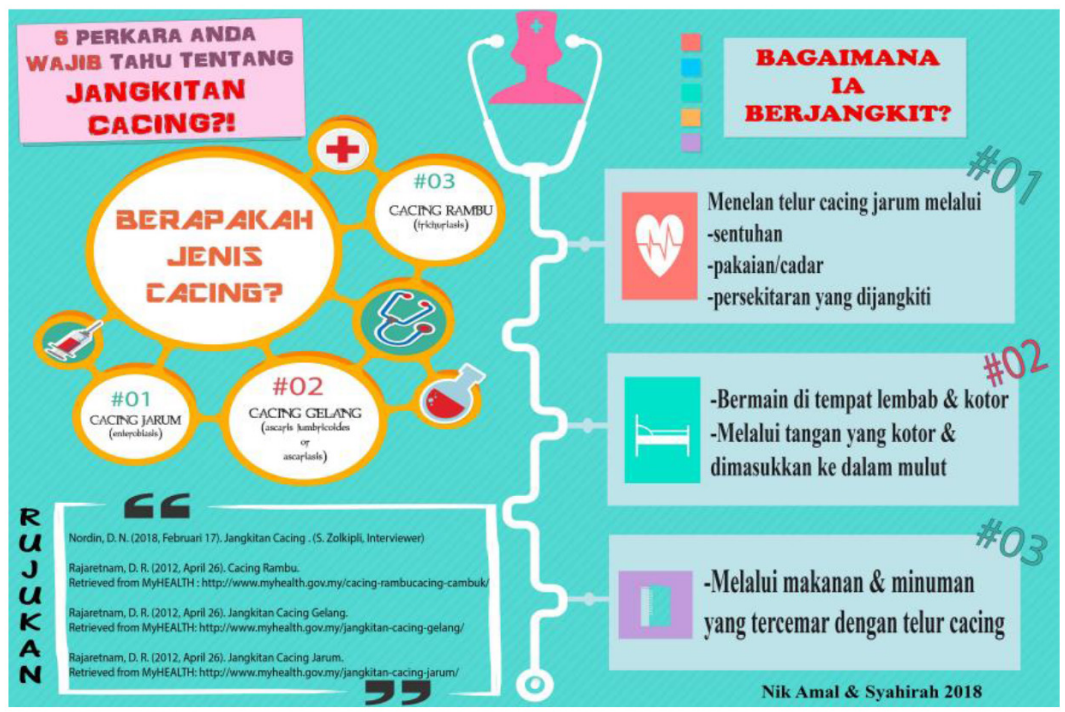

Rajah 3. Infografik Pelajar 12 dan 13 


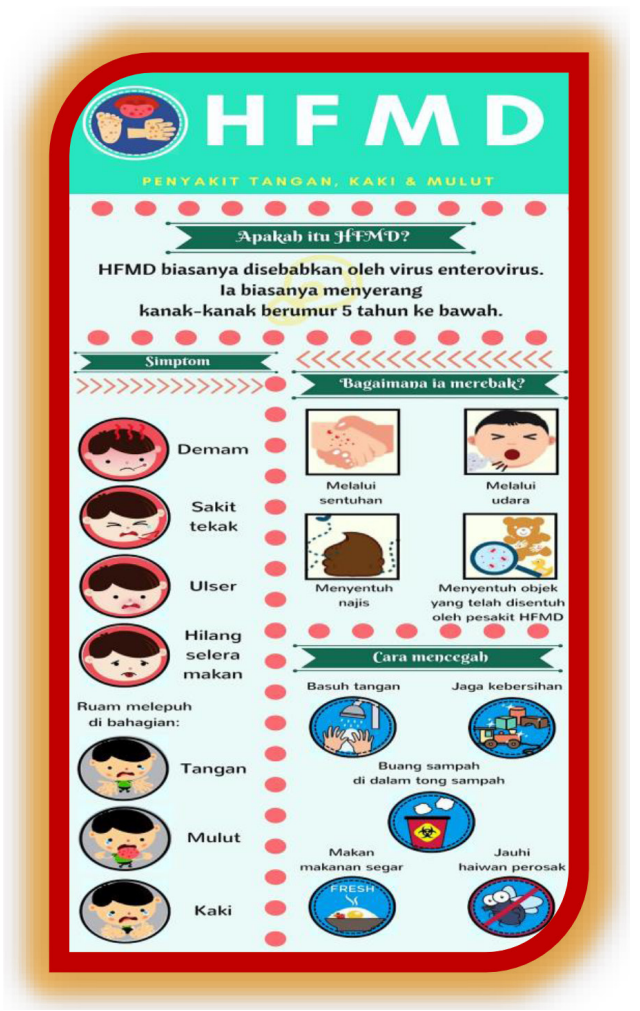

Rajah 4. Infografik Pelajar 23 dan 24

\section{Infografik Meningkatkan Pengetahuan Konsep Pelajar Tentang Penyakit Kanak-Kanak}

Tema pertama yang muncul dalam kajian ini adalah infografik dapat meningkatkan pengetahuan konsep berkaitan penyakit kanak-kanak. Secara umumnya, pelajar dalam kajian ini bersetuju bahawa infografik dapat meningkatkan kefahaman mereka terhadap konsep penyakit dalam kalangan kanak-kanak kerana infografik merupakan salah satu cara untuk belajar dan mengingati sesuatu fakta dengan lebih berkesan kerana maklumat yang penting sahaja yang akan dimasukkan di dalam infografik. Disamping itu, Pelajar 26 turut menyatakan bahawa "infografik adalah salah satu teknik pembelajaran yang sangat fleksibel kerana infografik membantu pelajar belajar secara visual agar topik tersebut dapat difahami dengan lebih baik dengan melihat gambar dan tulisan yang tidak terlalu padat" (Pelajar 26).

Infografik yang dihasilkan dalam tugasan ini adalah "sangat baik terutamanya untuk memaparkan data yang rumit ke dalam bentuk visual ringkas yang mudah 
difahami" (Pelajar 12). Seorang pelajar lain juga mengulas, "untuk menyampaikan konsep asas dalam kesihatan, saya menyedari bahawa infografik menyediakan platfom yang efisyen dalam menerangkan maklumat yang kompleks dengan penjelasan minimum" (Pelajar 1).

Bakal guru awal kanak-kanak ini turut menyatakan dalam menyediakan infografik, mereka perlu membuat kajian menyeluruh tentang penyakit kanak-kanak yang dipilih. Semasa proses ini, mereka bukan sahaja memperoleh pengetahuan baharu berkenaan penyakit yang dikaji, malah mereka turut mendapat maklumat berkenaan penyakit lain yang sering dialami oleh kanak-kanak. Ini memberi kesedaran bahawa sebagai seorang bakal pendidik, mereka haruslah mempunyai pengetahuan yang luas dalam isu berkaitan kesihatan kanak-kanak ini. Pelajar dalam kajian ini juga memahami bahawa maklumat yang diperoleh perlu berdasarkan sumber yang sahih dan berkredibiliti seperti portal myHEALTH oleh Kementerian Kesihatan Malaysia untuk mengelak mereka berkongsi maklumat yang tidak tepat. Pelajar juga membuat perbincangan dengan rakan-rakan sekelas dan juga bertanya terus kepada pengkaji tentang perkara yang kurang difahami, untuk mengelakkan salah faham tentang tajuk yang diberikan. Segelintir pelajar menyatakan mereka turut "menemuramah doktor di laman media sosial untuk bertanya lebih lanjut dengan penyakit kanak-kanak dan meminta doktor tersebut untuk memberi komen tentang infografik yang dihasilkan" (Pelajar 4). Proses pengumpulan maklumat ini menjadikan pembelajaran lebih bermakna dan seterusnya membantu pelajar menguasai pengetahuan konsep dalam isu ini.

\section{Infografik Mencipta Pengalaman Pembelajaran yang Bermakna}

Tema kedua ini menerangkan bagaimana bakal guru awal kanak-kanak berpendapat bahawa penyertaan mereka dalam tugasan inovatif ini telah mencipta pengalaman pembelajaran yang bermakna. Dapatan kajian menunjukkan bahawa apabila pelajar terlibat dalam proses pembelajaran secara langsung, mereka akan lebih bertanggungjawab terhadap pembelajaran mereka. Bakal guru awal kanak-kanak secara umumnya memberikan maklum balas yang positif terhadap tugasan ini walaupun semua pelajar menyatakan ini adalah kali pertama mereka diperkenalkan kepada laman web khusus untuk membina infografik seperti Canva, Piktochart dan Venngage. Pelajar 3 menyatakan tugasan infografik ini sebagai "tugasan yang paling menarik, berbanding dengan tugasan biasa yang melibatkan penyediaan laporan dan pembentangan" manakala Pelajar 7 "mencadangkan agar kursus lain menggunakan pendekatan seperti ini iaitu menggalakkan pelajar menggunakan pelbagai aplikasi atas talian dan berpeluang meneroka pengalaman baru, berbanding dengan kaedah laporan yang bersifat konvensional." 
Dalam kajian ini, pelajar diminta meneroka laman web yang berbeza dan membuat pemilihan mereka sendiri. Sebagai contoh, Pelajar 13 menjelaskan bahawa dia telah mencuba menggunakan Canva dan Piktochart dan memutuskan untuk menggunakan Canva kerana ia lebih mesra pengguna dan mempunyai banyak pilihan templat percuma. Pelajar 8 pula menyatakan bahawa dia mempelajari menggunakan Canva dengan menonton video tutorial di YouTube dan juga mencuba menggunakan Piktochart dan Venngage tetapi mendapati Canva adalah yang paling mudah digunakan dan mudah dinavigasi. Maklum balas dari pelajar mengesahkan bahawa tugasan seperti ini boleh menggalakkan pembelajaran kendiri melalui pelbagai sumber seperti video YouTube, video tutorial pada laman web infografik dan juga blog.

Integrasi tugasan berasaskan teknologi ini telah menyumbang secara positif kepada sikap bakal guru awal kanak-kanak tentang teknologi. Hasilnya, mereka menjadi lebih terdedah kepada penggunaan teknologi dan inovasi. Ini secara langsung menambah pengetahuan dan kemahiran baharu dalam teknologi sebagai persediaan mereka untuk menjadi guru dalam abad ke-21. Petikan berikut misalnya menggambarkan refleksi pelajar mengenai integrasi teknologi dalam kajian ini,

Dalam mendepani pembelajaran abad ke-21, teknologi dan multimedia perlu seiring dengan suasana pembelajaran semasa untuk membangunkan modal insan yang baharu. Kerana itu, saya merasakan ini adalah suatu kemahiran yang penting untuk dipelajari buat saya selaku bakal guru. (Pelajar 12)

Pada mulanya, saya mendapati tugasan ini amat berat kerana ianya tidak pernah dilakukan sama sekali dan merupakan tugasan yang paling mencabar sepanjang saya memasuki alam universiti. Namun, pada akhirnya saya mengakui yang ianya amat menarik dan memuaskan. Terdapat pelbagai aplikasi yang memudahkan saya membina sebuah infografik dengan mudah, pantas, dan menarik dengan mengaplikasi teknologi terkini. (Pelajar 21)

Bakal guru ini juga berkongsi keinginan mereka untuk memindahkan kemahiran dalam mencipta infografik ini dalam kerjaya mereka sebagai guru awal kanakkanak, seperti yang disebutkan oleh Pelajar 11 dalam petikan berikut:

Pengetahuan tentang infografik ini bermanfaat kerana ia berfungsi sebagai pendekatan alternatif dalam pengajaran di bilik darjah. Saya boleh mengintegrasikan kemahiran dalam membuat 
infografik dan pengetahuan dalam kerjaya saya dan menghasilkan bahan yang menarik dan mudah difahami oleh kanak-kanak.

Tugasan ini bukan sahaja menuntut pelajar untuk menguasai pengetahuan tentang penyakit kanak-kanak, malah mereka perlu mempamerkan kreativiti mereka dalam menyampaikan maklumat dengan tepat dan ringkas. Pelajar 19 mengakui:

Rupanya bukan senang untuk mencipta infografik yang dapat menarik perhatian orang ramai bagi membacanya. Bukan sahaja saya perlu fikir tentang isinya, tapi saya juga perlu fikir tentang grafik. Ini dapat mengasah pemikiran yang kreatif dan kritis.

Pelajar 2 pula menyatakan:

Saya perlu kreatif dalam memilih "font" dan saiz tulisan yang sesuai. Cara menyusun infomasi juga amat penting supaya pembaca tidak pening dengan perkataan yang terlalu banyak. Apabila hasil kerja dicetak dan ditampalkan pada dinding, saya berasa amat gembira dan teruja.

Oleh itu, dapatan kajian jelas menunjukkan tugasan infografik ini adalah mencabar bagi pelajar dan telah memberi kepuasan tersendiri apabila mereka berjaya menghasilkan infografik yang terbaik.

\section{Tugasan Membantu Bakal Guru dalam Memahami Ciri-Ciri Infografik yang Berkesan}

Dapatan yang diperoleh menunjukkan tugasan kreatif seperti ini dapat membantu bakal guru awal kanak-kanak dalam memahami ciri-ciri infografik yang baik, sebagai panduan kepada mereka dalam mencipta infografik yang berkesan. Infografik yang dihasilkan haruslah ringkas, tepat dan padat. Untuk menghasilkan sebuah infografik dengan ciri ini, pelajar perlu mempunyai kemahiran untuk menganalisa maklumat dan hanya mengambil maklumat yang penting untuk dimasukkan ke dalam infografik.

Infografik yang baik bukan sekadar mempunyai grafik yang menarik tetapi ia juga harus mempunyai struktur yang sesuai, maklumat yang tepat dengan kedalaman maklumat yang sepadan dengan tahap penerimaan pembaca. Dalam kajian ini, Pelajar 5 menjelaskan bahawa: 
Saya telah melihat pelbagai infografik yang dipersembahkan semasa sesi gallery walk dan mendapati perkara paling penting yang perlu dipertimbangkan adalah bagaimana untuk menyampaikan maklumat secara berkesan. Unsur visual yang digunakan dalam infografik harus dapat menyokong maklumat yang diberikan.

Pelajar juga menggemari infografik yang disertakan dengan gambar penyakit kerana memudahkan meraka untuk melihat sendiri bagaimana keadaan penyakit itu secara realiti, misalnya infografik berkaitan penyakit kulit iaitu ruam dan ekzema. Gambar yang disertakan memudahkan pelajar untuk membezakan penyakit tersebut.

Pelajar 9 pula menyatakan "infografik yang baik harus menyampaikan mesej yang betul". Antara cadangan pelajar adalah untuk "mengelakkan penggunaan ayat yang terlalu panjang dan mengelakkan daripada memilih tulisan dengan saiz yang kecil kerana sukar dibaca" (Pelajar 5). Penggunaan latar belakang berwarna gelap pula menyebabkan infografik menjadi gelap. Secara umumnya pelajar dalam kajian ini dapat memahami dan mengaplikasi ciri-ciri yang membezakan antara infografik yang baik dan yang kurang baik.

\section{PERBINCANGAN}

Kajian ini meneroka pandangan bakal guru awal kanak-kanak dalam penghasilan infografik dalam kursus berkaitan kesihatan dan keselamatan kanak-kanak. Infografik telah menjadi satu tren baharu dalam pendekatan pembelajaran hari ini kerana ia melibatkan visualisasi maklumat yang membolehkan pengetahuan dipamerkan dalam bentuk visual yang tersendiri (Ferreira et al., 2013; Lamb et al., 2014; Lazard \& Atkinson, 2015; Smiciklas, 2012).

Kajian menunjukkan bahawa projek berasaskan teknologi dapat memberi pengaruh positif terhadap pembelajaran aktif pelajar yang membolehkan mereka menghasilkan produk pembelajaran mereka secara kreatif. Meyer, Haywood, Sachdev dan Faraday (2008) mencadangkan perkara utama dalam pembelajaran kendiri adalah peralihan tanggungjawab dari pengajar kepada pelajar. Ini melibatkan pelajar memperoleh pemahaman tentang pembelajaran mereka, bermotivasi untuk belajar dan berkolaborasi dengan pengajar untuk menyusun persekitaran pembelajaran mereka sendiri. Dapatan ini juga disokong oleh kajian Artun (2016). Dalam kajian ini pelajar sangat bersemangat apabila diberi peluang untuk mengolah maklumat tentang penyakit kanak-kanak dan mempamerkannya 
dalam bentuk visual. Mereka menyifatkan bagaimana penglibatan mereka dalam tugasan inovatif ini telah mencipta pengalaman pembelajaran yang bermakna.

Penglibatan dalam kajian ini juga secara tidak langsung dapat membangunkan kemahiran yang berkaitan dengan pemprosesan secara kritikal konsep utama dalam penyakit yang dipilih. Mereka mengenal pasti kumpulan pembaca dan memutuskan maklumat terbaik yang harus dimasukkan dalam infografik mereka. Kemahiran memilih maklumat dianggap sebagai salah satu kemahiran literasi digital yang penting (Artun, 2016; Wilkes \& Hodson, 2013). Oleh itu, tugasan infografik membolehkan pelajar untuk mengaplikasi kemahiran penting seperti pengkhususan kandungan.

Pengkhususan kandungan adalah proses penyusunan pelbagai maklumat yang diperoleh di laman web dan menyampaikannya secara bermakna dan sistematik (Artun, 2016; Wilkes \& Hodson, 2013). Proses ini melibatkan penelitian dan pengaturan maklumat tentang sesuatu isu. Oleh itu, tugasan ini dapat meningkatkan pelbagai kemahiran termasuk kemahiran kognitif, kemahiran teknikal, kemahiran digital, kemahiran yang berkaitan dengan komunikasi maklumat dan kemahiran reka bentuk pengajaran yang inovatif, seperti yang dicadangkan oleh kajian sebelum ini (contohnya Artun, 2016; Hart, 2013; Wilkes \& Hodson, 2013; Yildirim, 2017).

Kajian ini telah membuktikan bagaimana tugasan infografik dapat mencabar dan menggalakkan literasi digital-visual pelajar. Tugasan infografik jelas memberi impak positif bakal guru terhadap penggunaan teknologi. Penemuan ini sepadan dengan dapatan yang diperoleh oleh Reed (2007), ChanLin (2008) dan Sasova (2011). Bakal guru juga mengakui bahawa mereka telah menjadi lebih terbuka terhadap penggunaan teknologi dan inovasi dalam pengajaran dan pembelajaran di universiti.

Tugasan infografik juga meningkatkan pengetahuan konsep berkaitan penyakit kanak-kanak seperti penyakit kaki, tangan dan mulut, jangkitan cacing, batuk, demam campak, penyakit telinga dan penyakit mata. Berdasarkan kajian yang dijalankan oleh Sacopla dan Yangco (2016), guru digalakkan untuk melengkapkan diri dengan kemahiran dalam mereka bentuk infografik terutamanya untuk pelajar yang lebih cenderung kepada gaya pembelajaran berbentuk visual untuk memudahkan mereka mengingat kembali dan mengekalkan maklumat penting yang membawa kepada pemahaman konseptual. Dapatan ini konsisten dengan penyelidikan lain yang mendapati bahawa representasi visual adalah salah satu alat yang paling berkesan dalam komunikasi konsep sains (Ferreira et al., 2013; Lamb et al., 2014; Lazard \& Atkinson, 2015). Dapatan ini mungkin boleh dijelaskan oleh fakta bahawa proses pengolahan kandungan membantu dalam meringkaskan 
kandungan saintifik dan mengenepikan maklumat yang tidak relevan. Ini menjadikan konsep saintifik lebih teratur dan terhubungkait dengan pengetahuan lepas. Guru awal kanak-kanak secara kritis menganalisis, meneroka, menilai dan membuat refleksi terhadap hasil karya mereka tentang topik yang dipilih. Oleh itu, hasil kajian ini menggalakkan penggunaan infografik dalam meningkatkan pemahaman konseptual terutamanya dalam pengajaran topik yang kompleks.

Tema ketiga yang muncul dalam kajian ini memperihalkan ciri infografik yang baik berdasarkan perspektif bakal guru. Mereka berpendapat bahawa infografik bukan sahaja perlu menarik secara grafik tetapi juga perlu mempunyai struktur yang padat, kandungan yang tepat dan kedalaman maklumat yang sesuai. Ini adalah selaras dengan Ware (2012) yang mencirikan infografik yang berkesan adalah infografik yang dapat menyampaikan intipati atau asas sesuatu konsep tanpa memerlukan seseorang untuk membaca teks yang berkaitan dengan teliti. Pelajar mesti memikirkan urutan logik untuk membentangkan kandungan dengan cara yang menarik, kesesuaian gambar yang dipilih, dan jenis infografik yang sesuai untuk menyampaikan idea utama. Sekiranya gambar yang dipilih tidak bersesuaian, ia boleh menjadi halangan bagi pembaca untuk memahami idea utama bagi sesebuah infografik (Abilock \& Williams, 2014; Lamb et al., 2014; Yildirim, 2017).

Bakal guru dalam kajian ini menjelaskan bahawa infografik yang baik harus dapat menyampaikan maklumat yang rumit dengan berkesan, iaitu dengan mengintegrasikan visual dan teks dalam penyampaian maklumat. Dapatan ini adalah selari dengan kajian lepas (contohnya Davidson, 2014; Lamb et al., 2014; Smiciklas, 2012; Yildirim, 2017) yang menyatakan infografik harus merangkumi maklumat yang jelas dan tepat dalam satu visual. Walaupun bakal guru mengakui penyediaan infografik memakan masa kerana ini merupakan pengalaman pertama mereka dalam membuat infografik, mereka semua bersetuju bahawa tugasan ini mrupakan pengalaman yang sangat berharga. Menurut Hashiroh dan Norshuhada (2017), integrasi teknologi dalam pedagogi secara tidak langsung dapat memotivasikan pelajar selain mewujudkan pembelajaran yang bermakna dan meningkatkan pemahaman pelajar. Dapatan kajian ini juga disokong oleh Kos dan Sims (2014).

Terdapat juga limitasi dalam menyediakan infografik iaitu perisian dan laman web percuma mempunyai akses yang terhad. Satu lagi masalah yang ketara melibatkan pelajar yang kurang mahir dalam teknologi. Mereka mengambil sedikit masa untuk mempelajari cara menggunakan perisian sebelum mereka memperoleh kemahiran dalam membuat infografik. Dapatan ini sepadan dengan dapatan dari kajian Kos dan Sims (2014) dan Yildirim (2017). 


\section{KESIMPULAN}

Kajian ini meneroka pengalaman dan pandangan bakal guru awal kanak-kanak dalam penghasilan infografik berkaitan penyakit kanak-kanak. Berdasarkan dapatan kajian, dapat disimpulkan bahawa penghasilan infografik mendorong kepada inovasi dan penggunaan teknologi dalam pengajaran dan pembelajaran kursus Kesihatan dan Keselamatan. Tugasan infografik mencipta pengalaman yang bermakna kepada bakal guru awal kanak-kanak dimana bakal guru boleh menggunakan infografik dalam pembangunan bahan-bahan pengajaran mereka kelak. Infografik telah diterima sebagai instrumen yang sesuai yang dapat meningkatkan pemahaman pengetahuan konseptual dengan menyediakan cara yang menarik dalam menjelaskan konsep saintifik berkaitan penyakit kanakkanak. Kajian ini juga dapat membantu bakal guru dalam memahami ciri-ciri infografik yang berkesan. Tugasan kreatif seperti ini memerlukan pelajar untuk mempraktikkan kemahiran teknologi digital. Setakat ini, tidak banyak kajian yang dijalankan untuk menerokai keberkesanan penggunaan infografik dalam pendidikan guru dan pendidikan kesihatan. Walaupun terdapat batasan dalam kajian ini kerana ia berskala kecil dengan bilangan peserta kajian yang terhad, dapatan kajian ini membuktikan keperluan mewujudkan kaedah penilaian alternatif dalam kursus di peringkat universiti.

\section{RUJUKAN}

Akinde, T. A. (2016). Theoretical modelling to explain lecturers' use of educational support systems for teaching in university-based library schools in Nigeria: Extending the technology acceptance model (TAM). Library Philosophy and Practice, 1416, 1-24. https://doi.org/10.1080/10572317.2017.1270695

Abilock, D., \& Williams, C. (2014). Recipe for an infographic. Knowledge Quest, 43(2), 46-55.

Artun, H. (2016). Examining the influence of projects carried out with technological tools on pre-service teachers' levels of environmental literacy. Journal of Baltic Science Education, 15(2), 173-184.

Bryman, A. (2006). Integrating quantitative and qualitative research: How is it done? Qualitative Research, 6(1), 97-113. https://doi.org/10.1177/1468794106058877

ChanLin, L. J. (2008). Technology integration applied to project-based learning in science. Innovations in Education and Teaching International, 45(1), 55-65. https://doi. org/10.1080/14703290701757450

Dabbagh, N., \& Kitsantas, A. (2012). Personal Learning Environments, social media, and self-regulated learning: A natural formula for connecting formal and informal learning. The Internet and Higher Education, 15(1), 3-8. https://doi.org/10.1016/j. iheduc.2011.06.002 
Davidson, R. (2014). Using infographics in the science classroom. The Science Teacher, 81(3), 34. https://doi.org/10.2505/4/tst14_081_03_34

Dias, L. B., \& Atkinson, S. (2001). Technology integration: Best practices-Where do teachers stand? IEJLL: International Electronic Journal for Leadership in Learning, 5(11), 5.

Dunlap, J. C., \& Lowenthal, P. R. (2016). Getting graphic about infographics: Design lessons learned from popular infographics. Journal of Visual Literacy, 35(1), 4259. https://doi.org/10.1080/1051144X.2016.1205832

Fadzil, H. M. (2018). Designing infographics for the educational technology course: Perspectives of pre-service science teachers. Journal of Baltic Science Education, 17(1), 8-18.

Ferreira, C., Baptista, M., \& Arroio, A. (2013). Teachers' pedagogical strategies for integrating multimedia tools in science teaching. Journal of Baltic Science Education, 12(4), 509-524.

Glaser, B. G., \& Strauss, A. (1967). The discovery of grounded theory: Strategies for qualitative research. New York: Aldine. https://doi.org/10.1097/00006199196807000-00014

Golafshani, N. (2003). Understanding reliability and validity in qualitative research. The Qualitative Report, 8(4), 597-607.

Grieve, R., Padgett, C. R., \& Moffitt, R. L. (2016). Assignments 2.0: The role of social presence and computer attitudes in student preferences for online versus offline marking. The Internet and Higher Education, 28(2), 8-16. https://doi. org/10.1016/j.iheduc.2015.08.002

Greene, J. C., Caracelli, V. J., \& Graham, W. F. (1989). Toward a conceptual framework for mixed-method evaluation designs. Educational Evaluation and Policy Analysis, 11(2), 255-274. https://doi.org/10.3102/01623737011003255

Hart, G. (2013). Effective infographics: Telling stories in the technical communication context. Retrieved from https://techwhirl.com/effective-infographics-tellingstories-in-the-technical-communication-context/

Hashiroh, H., \& Norshuhada, S. (2017). Persepsi pereka bentuk (guru) terhadap kualiti garis panduan pembangunan media pengajaran berkonsepkan penceritaan digital untuk tablet skrin sentuh. Malaysian Journal of Learning and Instruction (MJLI), 14(2), 271-292. https://doi.org/10.32890/mjli2017.14.2.10

Kos, B. A., \& Sims, E. (2014). Infographics: The new 5-paragraph essay. Proceedings of the 2014 Rocky Mountain Celebration of Women in Computing. Laramie, WY, USA: University of Colorado.

Krauss, J. (2012). Infographics: More than words can say. Learning \& Leading with Technology, 39(5), 10-14.

Krum, R. (2014). Cool infographics: Effective communication with data visualization and design. San Francisco, CA: John Willey \& Sons.

Lamb, G. R., Polman, J. L., Newman, A., \& Smith, C. G. (2014). Science news infographics: Teaching students to gather, interpret, and present information graphically. The Science Teacher, 81(3), 25-30. https://doi.org/10.2505/4/tst14_081_03_25

Lamb, A. \& Jhonson, L. (2014). Infographics part 1: Invitations to inquiry. Teacher Librarian, 41(4), 54-58. 
Lankow, J., Ritchie, J., \& Crooks, R. (2012). Infographics: The power of visual storytelling. San Francisco, CA: John Wiley \& Sons.

Lazard, A., \& Atkinson, L. (2015). Putting environmental infographics center stage: The role of visuals at the elaboration likelihood model's critical point of persuasion. Science Communication, 37(1), 6-33. https://doi.org/10.1177/1075547014555997

Lester, P. M. (2011). Visual communication: Images with messages. Boston, MA: Wadsworth.

Lye, L. T. (2013). Opportunities and challenges faced by private higher education institution using the TPACK model in Malaysia. Procedia-Social and Behavioral Sciences, 91, 294-305. https://doi.org/10.1016/j.sbspro.2013.08.426

McLoughlin, C. (2011). What ICT-related skills and capabilities should be considered central to the definition of digital literacy? Educational Multimedia, Hypermedia and Telecommunications, 12(1), 471-475.

Meeusah, N., \& Tangkijviwat, U. (2013). Effect of data set and hue on a content understanding of infographic. Proceeding of the Thanyaburi: Blooming Color for Life, 272-275. Retrieved from http://www.repository.rmutt.ac.th/xmlui/ handle/123456789/1263

Meyer, B., Haywood, N., Sachdev, D., \& Faraday, S. (2008). What is independent learning and what are the benefits for students. Schools and Families Research Report 051. London: Department for Children Schools and Families. Retrieved from http://www.curee.co.uk/files/publication/[site-timestamp]/ Whatisindependentlearningandwhatarethebenefits.pdf

Moreno, R., Mayer, R., Spires, H., \& Lester, J. (2001). The case for social agency in computer-based teaching: do students learn more deeply when they interact with animated pedagogical agents? Cognition and Instruction, 19(2), 177-213. https:// doi.org/10.1207/S1532690XCI1902_02

Patton, M. Q. (2002). Qualitative evaluation and research methods (3rd ed.). Thousand Oaks, CA: Sage.

Potter, J., \& Banaji, S. (2012). Social media and self-curatorship: Reflections on identity and pedagogy through blogging on a master's module. Comunicar, 19(38), 8391. https://doi.org/10.3916/C38-2012-02-09

Reed, P. A. (2007). The journey towards technological literacy for all in the united states: Are we there yet? The Technology Teacher, 12(3),15-22.

Ritchie, J., \& Spencer, E. (1994). Qualitative data analysis for applied policy research. In A. Bryman \& R. G. Burgess (Eds.), Analyzing qualitative data (Chapter 9). London, UK: Routledge. https://doi.org/10.4324/9780203413081_chapter_9

Saat, R. M., Fadzil, H. M., Aziz, A., Azlina, N., Haron, K., Rashid, K. A., \& Shamsuar, N. R. (2016). Development of an online three-tier diagnostic test to assess preuniversity students' understanding of cellular respiration. Journal of Baltic Science Education, 15(4), 532-546.

Sacopla, M. C. M., \& Yangco, R. T. (2016). Infographics: Effects on student coding skills and conceptual understanding in Biology. Proceeding of The Philippines, The Asian Conference on Education 2016, 123-133.

Sasova, I. A. (2011). Technological education or labor training? Russian Education and Society, 53(6), 49-65. https://doi.org/10.2753/RES1060-9393530604 
Siricharoen, W. V., \& Siricharoen, N. (2015). How infographic should be evaluated? Proceedings of the 7th International Conference on Information Technology (ICIT 2015), 558-564. https://doi.org/10.15849/icit.2015.0100

Smiciklas, M. (2012). The power of infographics: Using pictures to communicate and connect with your audiences. Canada: Que Publishing.

Toth, C. (2013). Revisiting a genre: Teaching infographics in business and professional communication courses. Business Communication Quarterly, 76(4), 446-457. https://doi.org/10.1177/1080569913506253

Vanichvasin, P. (2013). Enhancing the quality of learning through the use of infographics as visual communication tool and learning tool. Proceedings of the ICQA 2013 International Conference on QA Culture: Cooperation or Competition, 135-146.

Ware, C. (2012). Information visualization: Perception for design. Amsterdam, Netherlands: Elsevier.

Wilkes, G., \& Hodson, J. (2013). Using social media aggregation and curation techniques in the classroom to identify discourse trends and support brand operations. Proceeding of the Professional Communication Conference (IPCC), 2013 IEEE International, 1-7. https://doi.org/10.1109/IPCC.2013.6623896

Wolf, D., Beckem, J., \& Matias, A. (2011). Interactive technologies: Enhancing academic learning and stimulated student engagement with social media. In T. Bastiaens \& M. Ebner (Eds.), Proceedings of EdMedia: World Conference on Educational Media and Technology 2011 (pp. 2639-2644). Waynesville, NC: Association for the Advancement of Computing in Education (AACE).

Yildirim, S. (2017). Approaches of designers in the developed educational purposes of infographics'design processes. European Journal of Education Studies, 3(1), 249-284. 